\title{
The Effect of Return on Assets, Return on Equity, Net Profit Margin, Earning per Share, and Operating Profit Margin on Stock Prices of Banking Companies In Indonesia Stock Exchange
}

\author{
Choiriyah Choiriya ${ }^{1}$, Fatimah Fatimah ${ }^{2}$, Sri Agustina ${ }^{3}$, Fithri Atika Ulfa ${ }^{4}$, \\ ${ }^{1,2}$ Department of Management, Universitas Muhammadiyah Palembang, Indonesia \\ ${ }^{3 .}$ Sekolah Tinggi Ilmu Ekonomi Rahmaniyah, Sekayu-Musi Banyuasin, Indonesia \\ 4 Universitas Padjadjaran Bandung, Indonesia
}

choiriyah.ump17@gmail.com

\begin{abstract}
:
This study aims to determine the effect of return on assets (ROA), return on equity (ROE), net profit margin (NPM), earning per share (EPS) and operating profit margin (OPM) on the stock prices of banking companies on the Indonesia Stock Exchange. This type of research is associative research. Secondary data in this study is in the form of banking financial statements. The total population used in this study were 32 banking companies, and the samples that met the research criteria were eight banking companies listed on IDX. The analytical model used in this study is multiple linear regression analysis. The analysis results show that ROA, ROE, NPM, EPS, and OPM together have a significant effect on the stock prices of banking companies on the Indonesia Stock Exchange (IDX). On the other hand, coefisiens of ROA, NPM and OPM have no significant effect on the stock price of banking companies on the Indonesia Stock Exchange (IDX). In contrast, ROE and EPS significantly affect the stock price of banking companies on the Indonesia Stock Exchange (IDX).
\end{abstract}

Keywords: Return on assets; Return On Equity; Net Profit Margin; Earning Per Share; Operating Profit Margin; Stock Price.

\section{How to Cite}

Choiriyah, C., Fatimah, F., Agustina, S, \& Ulfa, F. A. (2021). The effect of return on assets, return on equity, net profit margin, earning per share, and operating profit margin on stock prices of banking companies in Indonesia Stock Exchange. International Journal of Finance Research, 2(1). 103-123. DOI : https://doi.org/10.47747/ijfr.v1i2.280..

\section{Introduction}

The financial performance becomes a separate tool for companies to obtain an assessment from the public, including potential investors who want to invest their capital in companies whose financial performance is considered healthy by investors. Before the company's financial statements are distributed to the public, the company has analyzed its financial statements using financial ratio analysis to determine whether its financial performance is good or bad.

Published by:

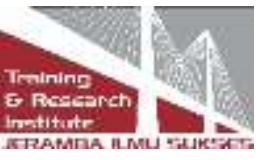


The stock price on the exchange is not always fixed, sometimes it increases, and it can also decrease, depending on the strength of demand and supply. In the capital market, fluctuations in stock prices make the stock market attractive to some investors. On the other hand, increases and decreases in stock prices can occur due to fundamental, psychological, or external factors. Several macro factors affect stock investment activities on the IDX, including inflation rates, interest rates, foreign exchange rates, and others. The high rate of inflation can result in the movement of the stock price index on the IDX. The stock price is a significant factor from the capital market activity and must be considered by investors in investing because the stock price shows the issuer's performance. The movement of stock prices is in line with the company's performance; if the company has better performance, the profits will be greater, and vice versa; therefore, every company issuing shares is very concerned about its share price. Prices that are too low often mean that the company's performance is not good.

Harahap (2015: 297) states that financial ratios are numbers obtained from comparing one financial statement account with other accounts with a relevant and significant relationship. Therefore, after using financial ratio analysis, financial managers in the company can predict the reactions of potential investors when they see the company's financial performance and can immediately take appropriate action when needed.

An analytical tool commonly known as financial ratio analysis can be used to measure the company's financial health. Financial ratios, in the relative and absolute sense, are tools that explain certain relationships between one number and another in financial statements. There are many ratios in the financial statements, but there are five ratios relatively often used by market participants: ROA, ROE, EPS, NPM. and OPM. ROA (return on assets) and ROE (return on equity), and EPS (earnings per share) and NPM (net profit margin) and OPM (operating profit margin) are ratios that investors often use to measure the performance of a company.

Return on assets (ROA) is a ratio that measures how efficient a company is in managing its assets to generate profits over a period. Operating Profit Margin (OPM) measures the percentage of each sale proceeds remaining after all expenses such as interest, taxes, preferred stock dividends are paid. Net profit margin (NPM) measures the percentage of each sale remaining after all costs and expenses, including interest, taxes, and preferred stock dividends, have been deducted. Operating profit margin (OPM) is obtained purely from the company's operating results. Therefore, operating profit also reflects how much efficiency and effectiveness of the company's operations to earn a profit.

Febriani's (2016) research produces a combined effect of ROA, ROE, EPS, and CR on stock returns, partially ROA has no significant effect on stock returns. ROE (return on equity) is a ratio to measure how much profit belongs to the owners of their capital. Hutami (2012) research the effect of DPS, ROE, and NPM on the stock price of manufacturing industry 
companies, Return on equity has a positive and significant effect on stock prices. EPS (earnings per share) or income per share is a form of giving benefits given to shareholders from each share owned (Fahmi, 2012: 85). Egam et al. (2017) the effect of ROA, ROE, NPM, and EPS on companies' stock prices that join the LQ45 Index, EPS has a positive effect on stock price listed on the LQ45 Index. Kamruzzaman Md, (2019) found that most factors have a positive relationship with ROA, and some factors have a weird relationship with ROA. There are several anomalies with few factors that affect ROA. The findings of this study have both theoretical and managerial significance - an initial investigation of factors or indicators that affect ROA. To find out the influence of these factors, this research studies ACME, a pharmaceutical company.

The return on assets (ROA) of several banks in 2018 fell drastically, but in 2019 it increased. Such as BNI, BRI and Mega Bank. Return on assets (ROA) of banking is very influential on financial performance. Return on investment, total asset turnover increases, which affects the profit margin, which is a profit for the company. The return on equity (ROE) of several banks in 2018 decreased, but in 2019 it increased. Such as BNI, BRI, Mandiri and Mega banks. Return on equity (ROE) Banking is very influential on financial performance. The higher the use of the company's capital, the higher the net profit. This will cause more and more investors to invest in their shares. In 2018, the NPM decreased. Nevertheless, in 2019, it increased. Net profit margin (NPM) of banking is very influential on financial performance. The higher the net profit margin (NPM), the higher the confidence of investors to invest in the company. In 2018 the EPS increased, but in 2019 it decreased. The better the performance of the issuer, the greater the influence on the increase in stock prices. In 2018 the operating profit margin (OPM) decreased. However, in 2019, it increased.

Based on this explanation, the researcher is interested in taking the title return on assets, return on equity, net profit margin, earning per share, and operating profit margin on the stock Price of banking companies in Indonesia Stock Exchange.

\section{Literature Review}

\subsection{Stock price}

Market power can be the spearhead in determining the value of the company. If the market judges that the issuing company is in good condition, the stock price will rise. According to Munawir (2012), "share prices that occur on the stock market at a certain time determined by market participants and capital." The stock price is formed in the capital market. It is determined by several factors such as earnings per share, the ratio of earnings to the price per share, the risk-free interest rate as measured by the government deposit interest rate and the level of certainty of its operations. Simatupang (2010:21), the market price of the shares of a publicly-traded company is the value traded on the Indonesia Stock Exchange.

There is not only one type of stock; several types of shares are most commonly used in the capital market and are most commonly known by the public. According to Fahmi and Hadi

Published by:

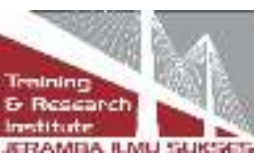


(2012: 86), "In the capital market, there are two types of shares that are most commonly known to the public: common stock and preferred stock, where the two types of shares have their respective meanings and rules.

\section{1) Common Stock}

Common stock is securities sold by a company that explains the nominal value (rupiah, dollar, yen and so on) where the holder is given the right to attend the general meeting of shareholders (GMS) and extraordinary general meeting of shareholders (EGMS). ) and has the right to decide whether to buy a rights issue or not. These shareholders, at the end of the year, will receive profits in the form of dividends.

2) Special Share

Preferred stock is securities sold by a company that explains the nominal value (Rupiah, dollar, yen, etc.) where the holder will receive fixed income in the form of dividends to be received quarterly (three months)

Munawir (2012) shares can be divided into 3, namely:

a) Preferred stock

Shares are shares that have the characteristics of a combination of bonds and ordinary shares. Compared to common stock, preferred stock has several rights, namely the right to a fixed dividend and the right to prepayment in the event of liquidation. Like bonds that pay interest on loans, the preferred stock also provides a fixed return in the form of preferred dividends. Therefore, preferred stock is considered to have characteristics midway between bonds and common stock.

\section{b) Common Stock}

If the company only issues one class of shares, these shares are usually in common stock. As owners of the company, common stockholders have several rights, including:

(1) Control rights are the rights of ordinary shareholders to choose the company's leadership.

(2) The right to receive profit sharing is the right of ordinary shareholders to share the company's profits.

(3) Preemptive rights, namely the right of shareholders to get the same percentage of ownership if the company issues additional shares to protect the control rights of the old shareholders and protect the price of the old shares from a decline in value.

(4) Treasury Stocks. Represents shares belonging to the company that has been issued and circulated, which are then repurchased by the company to be stored as treasury which can later be resold.

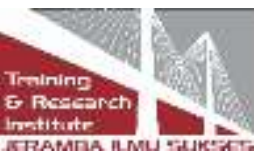


Darmadji \& Fakhrudin (2012:122), shares are divided into the transfer of rights (1). Bearer stock, meaning that the owner's name is not written on the stock to be easily transferred from one investor to another. (2). Shares on behalf of (restored stock) are written shares in the owner's name; the transfer method must be through specific procedures. From several definitions of the experts above, it can be concluded that the types of shares are divided into three, namely preferred shares, namely a combination of bonds and shares. Common stock, common stock, and treasury stock shares that have been previously issued and then repurchased.

Fahmi \& Hadi (2012: 89) there are several conditions and situations that determine a stock will fluctuate:

1) The influence of micro-economic factors and macro-economic factors

2) The company's decision to expand its business, such as opening new branch offices and sub-branches, both domestically and abroad.

3) There is a sudden reshuffle of directors

4) There are directors or commissioners involved in criminal acts

5) The company's performance has decreased at the end of the year

6) There are risks that occur as a whole in the company.

7) Market securities which were able to suppress the conditions of buying and selling shares.

The factors that influence the movement of stock prices are: (Munawir, 2012)

1) Internal factors include:

a) Announcements about marketing, production, sales such as advertising, contract details, price changes, new product recalls, production reports, product safety reports, and sales reports.

b) Announcements of funding (financing announcements), such as announcements related to equity and debt.

c) Management board of director announcements, such as changes and changes to directors, management, and organizational structure.

d) Announcements of diversified takeovers, such as reports on mergers, equity investments, reports on takeovers by acquirers and acquirers.

e) Investment announcements, such as adding business units, conducting research and development and closing businesses that are not profitable

f) Labor announcements, such as new negotiations, new contracts, strikes and others.

Published by:

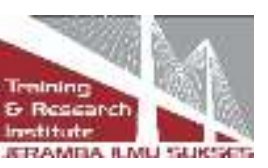


g) Announcement of company financial statements, such as profit planning before and after the end of the year, EPS (earnings per share), DPS (dividends per share), PER (price earning ratio), NPM (net profit margin), ROA (return on assets ), and others.

2) External Factors, namely:

a) ) Announcement of changes in interest rates for savings and time deposits, foreign exchange rates, inflation, as well as various economic regulations and deregulations issued by the government

b) Announcement of legal rules such as employee claims against the company or against its manager and the company's lawsuit against its manager.

c) Securities industry announcements, such as annual meeting reports, insider trading, trading volume or share prices, trading restrictions/suspensions.

\subsection{Profitability Ratio}

Profitability is a ratio to measure the company's ability shown to earn profits, in other words the use of profitability ratios will show the company's efficiency. According to Harahap (2015: 304) defines that the ratio describes the company's ability to earn profits through all existing sources such as sales activities, cash, capital, number of employees, number of branches and so on. Hanafi \& Halim (2016:81), the profitability ratio is "a ratio that measures the company's ability to generate profits (profitability) at a certain level of sales, assets, and share capital." Meanwhile, Fahmi (2012:212), states "profitability is the ratio of how the company is able to manage its foreign capital in order to earn profits and repay its debts". Sutrisno (2012: 217), "profitability will show how much profit the company can get".

The main goal to be achieved by the company is to obtain maximum profit. By obtaining the maximum profit that has been targeted, the company can improve the welfare of owners, employees, as well as improve product quality and make new investments. Management is required to meet the targets that have been set. Profitability ratios have goals and benefits for the company and investors, especially those who have an interest in the company.

Kasmir (2012: 196), the purpose of using profitability ratios for companies and parties outside the company are:

1) To measure or calculate the profit earned by the company in a certain period

2) To assess the company's profit position in the previous year with the current year

3) To assess profit development over time

4) To assess the amount of net profit after tax with own capital. Benefits of profitability ratios

5) To find out the amount of profit earned by the company in one period.

6) To compare the company's profit in the previous year with the current year.

7) To know the progress of profit from time to time.

Published by:

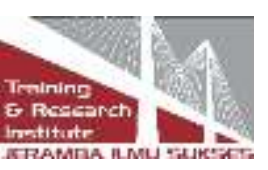


8) To compare net profit after tax with own capital.

9) To determine the effectiveness of the funds used, both foreign capital and own capital.

There are several types of profitability ratios that can be used to measure the company's ability. The types of liquidity ratios that companies can use to measure ability (Kasmir, 2012: 197) are:
a) NPM (Net Profit Margin)
b) ROI (Return on investment)
c) ROE (Return on equity)
d) EPS (Earning Per Share)

\subsection{Return On Assets.}

Return on Assets (ROA) is used to evaluate whether management has received a reasonable return from the assets under its control. This ratio is a useful measure if one wants to evaluate how well the company has used its funds. Kasmir (2012: 201), ROA (return on assets) is the ability of banking companies to generate profits with all assets owned by the company. Fahmi (2012: 98), Return on assets to see the amount of investment that has been invested in order to obtain the expected profit and the investment is a company asset. Tandelilin (2010: 372), Return On Assets is the company's ability to earn profits from the assets owned by the company.

According to Hanafi \& Halim (2016: 81), ROA is the company's ability to generate net income based on the number of assets. ROA is also often referred to as ROI (return on investment). ROI is also a measure of effectiveness in managing investments. Rosalina \& Masditok (2018), the greater the ROA or ROI, the better the performance because the higher the rate of return. So that it can attract investors to place their investment in the company, stock prices and company values summarize investors' collective assessments of how well a company is doing, both in terms of current performance and prospects. This shows that the return on assets affects the stock price of a company. Therefore, an increase in stock prices sends a positive signal from investors to managers. The company's value depends on the opportunity to grow, where this opportunity depends on its ability to attract capital.

\subsection{Return On Equity.}

Kasmir (2012:115), return on equity (ROE) or profitability of own capital, is a ratio to measure net profit after tax with own capital and generate net profit available to owners or investors. ROE shows the success or failure of the management in maximizing the return on investment of shareholders and emphasizes the return on income about the amount invested. ROE measures the return on investment of shareholders, using the formula for net income available to common shareholders divided by the number of common equity shares. Another name for ROE is own capital rentability (RMS), rate of return on stockholders investment and rate of return on net worth. Kasmi (2012:118) says that the higher the profitability ratio of

Published by:

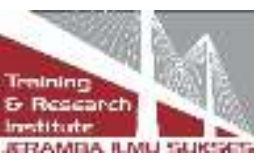


own capital, the better because this shows the amount of own capital in generating several profits, primarily net profit after tax. On the contrary, the smaller the profitability ratio of own capital means that the capital invested as operating cost only produces a small or low net profit after tax.

Return on equity (ROE) is a profitability ratio from the investor's point of view, not from the company's point of view. Return on equity (ROE) is a ratio to measure net profit after tax with own capital and generate net income available to owners or investors (Kasmir, 2012: 115). The calculation of ROE is obtained by dividing net profit after tax by own capital. Using return on equity (ROE) in this study is because ROE is an important measurement to determine how efficiently a company will use the money they invest in generating net income.

Return on equity (ROE) measures the rate of return on investment from shareholders (Brigham \& Houston, 2016: 78). ROE is the company's ability to generate profits by using its capital. ROE is also called the rate of return on the company's owner's equity; owner's equity is the company's total net assets. Thus, ROE measures the company's ability to earn profits available to shareholders of the company. This ratio is highly considered by shareholders because shareholders prefer high ROE.

In other words, the higher the ROE, the higher the use of own capital owned by the company can generate net income, the more investors will invest their funds (Wardjono, 2010: 58). Harahap (2015: 68) ROE shows the net profit percentage when measured by the owner's capital. Another definition of ROE is to measure the company's ability to obtain profits available to the company's shareholders. This ratio is also influenced by the size of the company's debt, and if the proportion of debt is more significant, then this ratio will also be even greater. In other words, ROE shows the success of management in maximizing the rate of return to shareholders. The higher this ratio, the better because it provides a greater rate of return to shareholders.

\subsection{Net Profit Margin}

Net profit margin (NPM) is a ratio that measures the percentage of sales after interest and taxes (Gitman, 2012:79-82). This ratio is significant for operations managers because it reflects its sales pricing strategy and ability to control operating expenses. Using net profit margin (NPM) in this study is because the more significant the NPM, the more productive the company's performance will be. This will increase investor confidence to invest in the company.

Net profit margin (NPM) measures its net profit compared to its sales (Brigham \&Houston, 2016: 48). Another case is the net income obtained from each sale. The bigger this ratio, the better because it is considered that its ability to earn profits is relatively high. NPM does not describe the percentage of net profit earned by the company for each sale due to the elements of income and non-operating costs. According to (Gitman, 2012), understanding net profit

Published by:

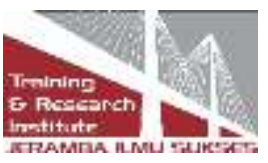


margin is a ratio that shows the achievement of profit on sales per Rupiah, which is calculated by comparing the profits earned with the sales generated.

The weakness of this ratio is to include items or items that are not directly related to sales activities, such as interest costs for financing and income tax costs. If the NPM is still below the industry average of $5 \%$, it indicates high costs. High costs usually occur due to inefficient operations (Brigham \& Houston, 2016: 48).

\subsection{Earnings Per Share.}

Earnings per share, also called book value, is a ratio to measure the success of management in achieving profits for shareholders (Kasmir, 2012: 113). Using earning per share (EPS) shows the amount of the company's net profit distributed to all company shareholders. Furthermore, it will provide information to outside parties (external) on how far the company can generate profits for each outstanding share.

\subsection{Operating Profit Margin.}

Operating profit margin (OPM) shows the company's ability to generate profits that will cover fixed costs or other operating costs (Harahap, 2015: 58). OPM is strongly influenced by the cost of goods sold. If the cost of goods sold increases, the OPM would decrease, and vice versa. The OPM ratio is found by net sales minus the cost of goods sold divided by net sales. This ratio helps know the company's gross profit from each item sold. The weakness of this ratio is that it only provides gross profit from sales made without including the existing cost structure of the company (Darsono \& Ashari, 2015: 68).

The ratio of operating profit margin (OPM) is found by net sales minus cost of goods sold divided by net sales, which is formulated as follows:

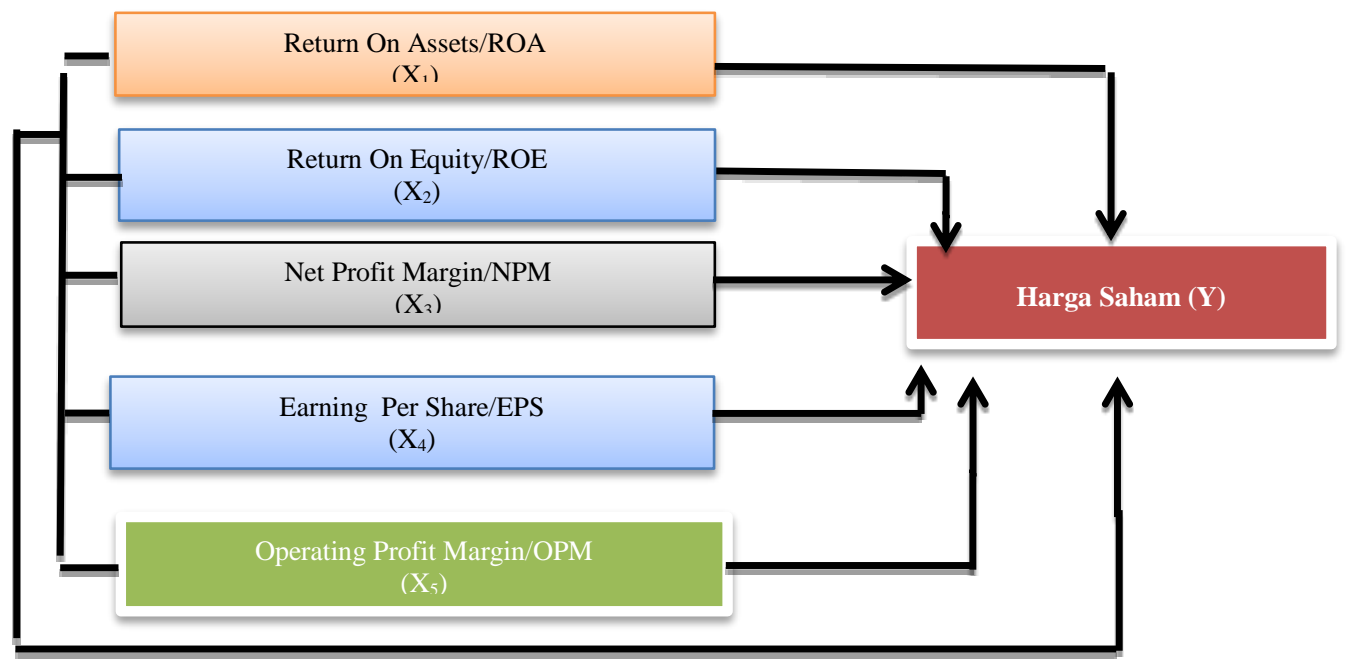

Picture 1. Research method

Published by:

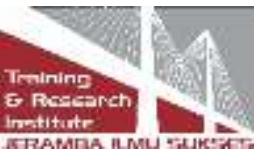




\section{Research Methods}

Research design is a working guideline so that research can run effectively and efficiently. Design is beneficial for research implementers and is helpful for all those involved in the research activity. The research design can be prepared based on the formulation of the problem and the hypothesis.

In this study, the type of data used is secondary data in the form of a quantitative time series for the $2015-2019$, namely data in numbers. The total population used in this study were 32 banking companies, and the samples that met the research criteria were eight banking companies

\subsection{Definition of Variable Operationalization}

The research variable is something that is studied, which can distinguish or change the value. Therefore, all variables in this study are described in the description, and each variable is developed into the following indicators:

Variable (Y): Share price is the price formed according to supply and demand in the stock trading market and is generally the closing price of banking companies on the IDX. The indicator is the closing stock price (closing price)

Variable (X1): Return on assets (ROA) is the ability of a banking company to maintain and improve its financial condition so that it does not lead the company to greater financial risk. As for the formula:

$$
R O A=\frac{\text { Earning After } \operatorname{Tax}(E A T)}{\text { Total Assets }}
$$

Variable (X2): ROE (Return on equity) is the success/failure of the management in maximizing the return on investment of shareholders and emphasizing the return on income with the amount invested. As for the formula:

$$
R O E=\frac{\text { Earning After Tax }(E A T)}{\text { Total Equity }}
$$

Variable (X3): Net profit margin (NPM) reflects the sales pricing strategy applied by the banking company and its ability to control operating expenses. As for the formula:

$$
N P M=\frac{\text { Earning After Tax }(E A T)}{\text { Sales }}
$$


Variable (X4): Earning per share (EPS) is the success of management in achieving profits for shareholders of banking companies. As for the formula:

$$
E P S=\frac{\text { Earning After } \operatorname{Tax}(E A T)}{\text { Total Shares Outstanding }}
$$

Variable (X5): Operating profit margin (OPM) is the ability of banking companies to generate profits that will cover fixed costs or operating costs. As for the formula:

$$
O P M=\frac{(\text { Net Sales }- \text { Cost of Goods Sold })}{\text { Net Sales }}
$$

The data analysis technique in this study uses multiple regression analysis techniques (multiple regression analysis) with the help of the SPSS 20 program. The stages of implementing the analysis include:

\subsection{Classical Assumption Model Test:}

1) Normality Test,

2) Multicollinearity Test,

3) Autocorrelation Test.

\subsection{Analysis Techniques}

\subsubsection{Multiple regression analysis}

Used to determine how much influence the variables $\mathrm{X} 1$ is return on assets (ROA), variable $\mathrm{X} 2$ is return on equity (ROE), variable X3 is net profit margin (NPM), variable X4 is earning per share (EPS) and variable X5 is operating profit margin (OPM) to share price (Y).

Multiple linear regression is used because the influence variable $(\mathrm{X})$ is more than one, with the formula:

$$
Y=a+b_{1} \cdot X_{1+} b_{2} \cdot X_{2}+b_{3} \cdot X_{3}+b_{3} \cdot X_{3}+b_{4} \cdot X_{4}+b_{5} \cdot X_{5}+\varepsilon
$$

Keterangan :

$\mathrm{Y} \quad=$ Stock price

a $\quad=$ Constant

$\mathrm{b}_{1}-\mathrm{b}_{5}=$ Coefficient Regression

$\mathrm{X}_{1} \quad=$ Return On Assets (ROA)

$\mathrm{X}_{2} \quad=$ Return On Equity $(\mathrm{ROE})$

$\mathrm{X}_{3} \quad=$ Net Profit Margin (NPM)

$\mathrm{X}_{4} \quad=$ Earning Per Share (EPS)

$\mathrm{X}_{5} \quad=$ Operating Profit Margin (OPM) 
$\varepsilon \quad=$ Error of Term

\subsubsection{Simultaneous testing (F test)}

Simultaneous test regression analysis (F-test) was carried out to prove the research hypothesis of the significant effect of the independent variables together on the dependent variable.

The test criteria are as follows:

Ho is rejected: $\operatorname{sig} \mathrm{F}<\alpha(0.05)$ or $\mathrm{F}$-count $>\mathrm{F}_{\text {-table }}$.

Ho is accepted: $\operatorname{sig} \mathrm{F} \geq \alpha(0.05)$ or $\mathrm{F}$-count $\leq \mathrm{F}_{\text {-table }}$.

Ho: there is no effect of return on assets, return on equity, net profit margin, earning per share, and operating profit margin, together on the stock price of banking companies on the Indonesia Stock Exchange.

Ha: there is an effect of return on assets, return on equity, net profit margin, earning per share, and operating profit margin, together on the stock price of banking companies on the Indonesia Stock Exchange.

\subsubsection{Partial test (t-test)}

Regression analysis of the partial test of each independent variable on the dependent variable can be explained by using the t-test. According to Fauzi et al. (2019), the test criteria are: Test the hypothesis with the t-test, namely testing the hypothesis of variable $\mathrm{X}$ on variable $\mathrm{Y}$ partially or one by one.

The test criteria are as follows:

Ho is rejected: $\operatorname{sig} \mathrm{t}<\alpha(0.05)$ and $\mathrm{t}_{- \text {coun }} \mathrm{t}>\mathrm{t}$-table.

Ho is accepted: $\operatorname{sig} \mathrm{t} \geq \alpha(0.05)$ and $\mathrm{t}_{\text {-count }} \leq \mathrm{t}$-table. $^{-}$

Ho: there is no effect of return on assets, return on equity, net profit margin, earning per share, and operating profit margin, partially on the stock price of banking companies on the Indonesia Stock Exchange.

Ha: there is an effect of return on assets, return on equity, net profit margin, earning per share, and operating profit margin, partially on the stock price of banking companies on the Indonesia Stock Exchange.

\section{Results and Discussion}

Data analysis carried out is classical assumption testing, multiple regression and hypothesis testing, as follows:

\subsection{Classic Assumption Model Test}

\subsubsection{Normality Test}

Published by:

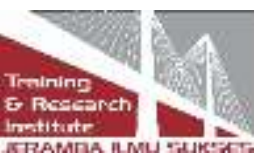


A normality test is used to determine whether the data used in the study is normally distributed or not. Normality test was carried out using Kolmogorof-Smirnov. The results of the analysis can be seen in the following Table 1

Table 1. Normality Test

\begin{tabular}{|c|c|c|c|c|c|c|}
\hline & & $\mathrm{ROA}$ & ROE & NPM & EPS & OPEN \\
\hline $\mathrm{N}$ & & 40 & 40 & 40 & 40 & 40 \\
\hline & Mean & $0 \mathrm{E}-7$ & $0 \mathrm{E}-7$ & $0 \mathrm{E}-7$ & $0 \mathrm{E}-7$ & $0 \mathrm{E}-7$ \\
\hline Normal Parameters ${ }^{\text {,b }}$ & $\begin{array}{l}\text { Std. } \\
\text { Deviation }\end{array}$ & .23025 & .2690 & .2086 & .126968 & .271708 \\
\hline & Absolute & .119 & .178 & .126 & .063 & .173 \\
\hline Most Extreme & Positive & .114 & .093 & .063 & .056 & .089 \\
\hline & Negative & -.119 & -.178 & -.126 & -.063 & -.173 \\
\hline Kolmogorov-Smirnov & & .752 & 1.124 & .796 & .396 & 1.095 \\
\hline Asymp. Sig. (2-tailed) & & .624 & .160 & .550 & .998 & .181 \\
\hline
\end{tabular}

Source: secondary data processing. 2020

Based on the table above, the significance value of each variable is obtained, namely ROA, a significance value of 0.624 ; ROE significance value of 0.160 ; NPM significance value is 0.550 ; EPS significance value is 0.998 , and OPM a significance value of 0.181 . All of the above significance values are greater than the alpha value of 0.05 . So it can be concluded that the data used are all normally distributed.

\subsubsection{Multicollinearity test}

To detect whether the data has multicollinearity or not, one of the methods used is Tolerance and VIF analysis. With the provisions, if the TOL value is above 0.1 and the VIF is below 10, it is said that there is no multicollinearity and vice versa. The results of the analysis can be seen in the following Table 2.

Table 2. Multikolinearity Test

\begin{tabular}{|c|c|c|c|}
\hline \multirow[t]{2}{*}{ Model } & & \multicolumn{2}{|c|}{ Collinearity Statistics } \\
\hline & & Tolerance & VIF \\
\hline \multirow{6}{*}{1} & (Const & & \\
\hline & ROA & .109 & 9.142 \\
\hline & ROE & .184 & 5.431 \\
\hline & NPM & .284 & 3.522 \\
\hline & EPS & .236 & 4.240 \\
\hline & OPEN & .575 & 1.738 \\
\hline
\end{tabular}

Source: secondary data processing. 2020

Published by:

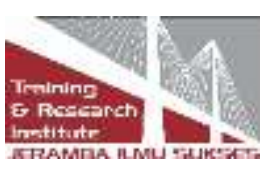


From the Table 2 below, the tolerance value is above 0.1 , and VIF is below 10 . So it can be said that there is no multicollinearity in the data.

\subsubsection{Autocorrelation Test}

The requirement that must be met is the absence of autocorrelation in the regression model. The test method that will be used is the Durbin-Watson test (DW test). This test is carried out to determine whether or not there is a deviation from the classical assumption of autocorrelation, namely the correlation between the residuals in one observation with other observations in the regression model.

Table 3. Uji Autokorelasi

\begin{tabular}{ll}
\hline Model & Durbin-Watson \\
\hline 1 & 1.477 \\
\hline
\end{tabular}

Source: secondary data processing. 2020

From the analysis results, the value of $\mathrm{DW}=1.477$ while the value of $\mathrm{dL}=1.23$ and $\mathrm{dU}=$ 1.79. So that $1.79>1.477<2.21$, then this value cannot be concluded that there is an autocorrelation.

\subsubsection{Analysis Techniques}

1) Multiple Linear Regression Analysis

The results of multiple linear regression analysis can be seen in the following Table 4

Based on the results of multiple linear regression analysis, the multiple linear regression equation models can be described as follows:

$$
\mathrm{Y}=2,303+0,159 \mathrm{X} \_1-0,473 X \_2-0,033 X \_3+0,689 X \_4-0,031 X \_5
$$

Tabel 4. Analisis Regresi Linier Berganda

\begin{tabular}{lllll}
\hline \multirow{2}{*}{ Model } & & \multicolumn{2}{l}{$\begin{array}{l}\text { Unstandardized } \\
\text { Coefficients }\end{array}$} & $\begin{array}{l}\text { Standardized } \\
\text { Coefficients }\end{array}$ \\
\cline { 3 - 5 } & & B & Std. Error & Beta \\
\hline \multirow{4}{*}{1} & (Constant) & 2.303 & .249 & \\
& ROA & .159 & .167 & .176 \\
& ROE & -.473 & .161 & -.418 \\
& NPM & -.033 & .111 & -.034 \\
& EPS & .689 & .081 & 1.078 \\
& OPEN & -.031 & .057 & -.044 \\
\hline
\end{tabular}

Source: secondary data processing. 2020

Published by:

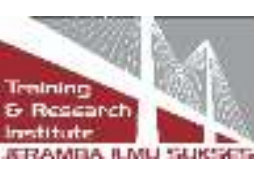


The equation model can be explained as follows:

a) The constant value is 2.303 and has a positive slope indicating that if the independent variable in the study is considered constant, the stock price will only increase by 2.303 .

b) The ROA parameter value is 0.159 and has a positive slope indicating that if the ROA is increased, for example, 1 per cent, the stock price will increase by 0.159 per cent.

c) The value of the ROE parameter is 0.473 and has a negative slope indicating that if the ROE is increased, for example, by 1 per cent, the stock price will decrease by 0.473 per cent.

d) The NPM parameter value is 0.033 and has a negative slope indicating that if the NPM is increased, for example, 1 per cent, the stock price will decrease by 0.033 per cent.

e) The EPS parameter value is 0.689 and has a positive slope indicating that if EPS is increased, for example, 1 per cent, the stock price will increase by 0.689 per cent.

f) The OPM parameter value is 0.031 and has a negative slope indicating that if the OPM is increased by 1 per cent, the stock price will decrease by 0.031 per cent.

\subsubsection{Simultaneous Testing (F Test)}

Table 5. ANOVA

\begin{tabular}{ccccccc}
\hline \multirow{2}{*}{ Model } & $\begin{array}{c}\text { Sum of } \\
\text { Squares }\end{array}$ & Df & Mean Square & F & Sig. \\
\hline \multirow{2}{*}{1} & Regression & 2.936 & 5 & .587 & 46.659 & $.000^{\mathrm{b}}$ \\
& Residual & .428 & 34 & .013 & & \\
\hline & Total & 3.364 & 39 & & & \\
\hline
\end{tabular}

Source: secondary data processing. 2020

The analysis results The Table 5 above shows that $\mathrm{F}_{\text {-count }}$ is $46.659>\mathrm{F}_{\text {-table }}$ is 2.53 , so it can be concluded that Ho is rejected. Ha is accepted, which means that the ROA, ROE, NPM, EPS, and OPM variables together have a significant effect on the stock price variable.

\subsubsection{Partial Test (T-Test)}

The partial test of the effect of the independent variable on the dependent variable can be seen in the following Table 6. 
Table 6. Coefficient

\begin{tabular}{llll}
\hline Model & & $\mathrm{t}$ & Sig. \\
\hline \multirow{2}{*}{1} & (Constant) & 9.260 & .000 \\
& ROA & .952 & .348 \\
& ROE & -2.933 & .006 \\
& NPM & -.299 & .767 \\
& EPS & 8.560 & .000 \\
& OPEN & -.550 & .586 \\
\hline
\end{tabular}

Source: secondary data processing. 2020

In this test, the partial effect of each independent variable on the dependent variable can be explained using the t-test with the following tests:

a) The significance value of the ROA variable on the stock price is 0.348 . Therefore, the value of sig $\mathrm{t}$ is $0.348>(0.05)$; this means that ROA does not affect stock prices.

b) The significance value of the ROE variable on the stock price is 0.006 . The value of sig $\mathrm{t}$ is $0.006<(0.05)$. This means that there is an effect of ROE on stock prices.

c) The significance value of the NPM variable on the stock price is 0.767 . The value of sig $t$ is $0.767>(0.05)$. This means that there is no effect of NPM on stock prices.

d) The significance value of the EPS variable on the stock price is 0.000 . The value of sig $t$ is $0.000<(0.05)$. This means that there is an effect of EPS on stock prices.

e) The significance value of the OPM variable on the stock price is 0.586 . The value of sig $\mathrm{t}$ is $0.586>(0.05)$. This means that there is no effect of OPM on stock prices.

\subsection{Discussion}

4.2.1. Effect of ROA, ROE, NPM, EPS, OPM on the stock price of banking companies on the Indonesia Stock Exchange (IDX)

The F test hypothesis analysis (together) show that F-count is 46,659 > F-table is 2,53, so it can be concluded that Ho is rejected. Ha is accepted, which means that the ROA, ROE, NPM, EPS, and OPM variables together affect the stock price variable.

According to Keown et al. (2012:86), stock prices are influenced by return on assets, return on equity, net profit margin, earning per share, and operating profit margin. These ratios calculate net income after tax with sales, which measure each Rupiah of sales. In addition, the profit margin is used to calculate the extent to which the company can generate net profit at a certain level of sales. 
In line with research conducted by Sitorus and Elinarty (2017), and Febriani (2016), his research concludes that there is an effect of return on assets, return on equity, net profit margin, earning per share, and operating profit margin together. -identical to the share price.

4.2.2. The effect of ROA on the stock price of banking companies on the Indonesia Stock Exchange (IDX)

The results of the partial hypothesis analysis show that the t-count value is 0.952 and has a positive slope which is smaller than the t-table 1 value of 2.021. In addition, the significance value of 0.348 is greater than the alpha value of 0.05 , so it can be concluded that Ho is accepted, meaning that there is no significant effect of ROA on stock prices.

ROA is also often referred to as ROI (return on investment). ROI is also a measure of the effectiveness of management in managing its investments. The greater the ROA or ROI, the better the performance because the higher the rate of return. So that it can attract investors to place their investment in the company, stock prices and company values summarize investors' collective assessments of how well a company is doing, both in terms of current performance and prospects. Therefore, an increase in stock prices sends a positive signal from investors to managers. The company's value depends on the opportunity to grow, where this opportunity depends on its ability to attract capital. This shows that the return on assets affects the stock price of a company.

This research is in line with Atidhira (2017) research that, first, return on assets (ROA) does not affect stock prices. Second, return on assets (ROA) and firm size have a negative and insignificant effect on stock returns.

4.2.3. The effect of roe on the stock price of banking companies on the Indonesia Stock Exchange (IDX)

The results of the partial hypothesis analysis show that the t-count value is 2.933 and has a negative slope which is smaller than the t-table value of -2.021. In addition, the significance value of 0.006 is smaller than the alpha value of 0.05 , so it can be concluded that Ho is rejected, meaning that there is a significant effect of ROE on stock prices.

The higher the ROE indicates the use of own capital owned by the company, the higher it can generate net profit, the more investors will invest their funds. ROE shows what percentage of net profit is obtained when measured from the owner's capital. Thus, ROE is a measure of the company's ability to earn profits available to the company's shareholders.

This research is in line with research conducted by), Amriyani \& Choiriyah (2018); Cahyani \& Winarto (2017); Diaz and Jufrizen (2014), their research concludes, firstly, return on equity (ROE) affects stock prices. This shows that investors view Return on equity as a company fundamental that has little influence in making investment decisions.

Published by:

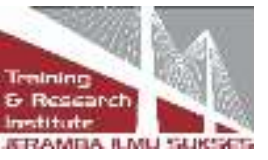


4.2.4. The influence of NPM on stock prices of banking companies on the Indonesia Stock Exchange (IDX)

The results of the partial hypothesis analysis show that the t-count value is 0.299 and has a negative slope more significant than the t-table value of -2.021. In addition, the significance value of 0.767 is greater than the alpha value of 0.05 , so it can be concluded that Ho is accepted, meaning that there is no significant effect of NPM on stock prices.

Net profit margin (NPM) in this study because the more significant the NPM, the more productive the company's performance will be. This will increase investor confidence to invest in the company. Net profit margin (NPM) measures the company's net profit compared to its sales. Net profit margin is a ratio that shows the achievement of profit on sales per Rupiah which is calculated by comparing the profit earned with the sales generated. This ratio is significant for operations managers because it reflects its sales pricing strategy and ability to control operating expenses.

This research is in line with research conducted by Diaz \& Jufrizen (2014), Cahyani \& Winarto (2017) that, first, net profit margin (NPM) does not affect stock prices. Second, NPM has no significant effect on the closing price of shares.

\subsubsection{Effect of EPS on share prices of banking companies on the Indonesia Stock Exchange} (IDX)

The results of the partial hypothesis analysis show that the t-count value is 8.560 and has a positive slope which is greater than the t-table value of 2.021. In addition, the significance value of 0.000 is smaller than the alpha value of 0.05 , so it can be concluded that Ho is rejected, meaning that there is a significant effect of EPS on stock prices.

Securities analysts and shareholders are generally very concerned about the EPS ratio. The higher the return generated by a company, the higher the stock price will be. Furthermore, it will provide information to outside parties (external) on how far the company can generate profits for each outstanding share.

The results of this study are in line with Kamruzzaman Md (2019) research. The results of his research that there is an effect of the independent variables EPS (X1), ROE (X2), and NPM (X3) on the variable Stock Price. The EPS variable has the strongest influence compared to other variables, so the EPS variable is the variable that has the most dominant influence on the closing price of shares. Rosalina \& Masditok (2018) the EPS variable has the strongest influence compared to other variables; the EPS variable is the variable that has the most dominant influence on the closing price of shares

Cahyani \& Winarto (2017), the results of research partially earning per share (X2) has a significant positive effect on the stock price of PT Medco Energi Internasional Tbk. This shows that investors view earning Per-share as a company fundamental that has little influence in making investment decisions. Atidhira (2017) Earnings per Share (EPS)

Published by:

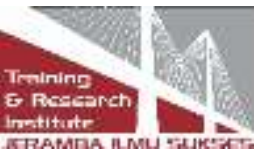


positively and significantly affects stock returns. Meanwhile, Return on assets (ROA) and company size have a negative and insignificant effect on stock returns.

4.2.6 Influence of OPM on share prices of banking companies on the Indonesia Stock Exchange (IDX)

The results of the partial hypothesis analysis show that the t-count value is 0.550 and has a negative slope greater than the t-table value of -2.021. In addition, the significance value of 0.586 is greater than the alpha value of 0.05 , so it can be concluded that Ho is accepted, meaning that there is no significant effect of OPM on stock prices.

Operating Profit Margin (OPM) shows the company's ability to generate profits that will cover fixed costs or other operating costs. The cost of goods sold shares strongly influences OPM. If the cost of goods sold increases, the OPM would decrease, and vice versa. Net sales find the OPM ratio minus the cost of goods sold divided by net sales. This ratio helps know the company's gross profit from each share sold.

In line with Alfianti A. and Andarini (2017) research, the results of his research show that the operating profit margin (OPM) variable has no significant effect on stock prices.

\section{Conclusions}

Based on the discussion that has been described, it can be concluded, among others:

a. ROA, ROE, NPM, EPS, and OPM together have a significant effect on the stock price of banking companies on the Indonesia Stock Exchange (IDX).

b. ROA, NPM and OPM have no significant effect on the stock price of banking companies on the Indonesia Stock Exchange (IDX). At the same time, ROE and EPS significantly affect the stock price of banking Companies on the Indonesia Stock Exchange (IDX).

The research gives an Implication such as:

a. Banking companies listed on the Indonesia Stock Exchange must maintain stability if necessary to increase ROA, ROE, NPM, EPS, and OPM to maintain and increase the stock price of banking companies.

b. Shareholders of banking companies listed on the Indonesia Stock Exchange do not immediately withdraw their shares when there is a decline in share prices because it is hoped that there will be stability and an increase in ROA, ROE, NPM, EPS and OPM so that they can maintain to increase the profitability of banking companies and return stock prices. 


\section{International Journal of Finance Research}

e-ISSN: 2746-136X.

Vol. 1, No. 2, December 2020

\section{References}

Alfianti A, D, \&Andarini, S. (2017). Pengaruh profitabilitas terhadap harga saham pada perusahaan makanan dan minuman yang terdaftar di Bursa Efek Indonesia. Jurnal Bisnis Indonesia, 8(1).

Amriyani, D.P., \& Choriyah. (2018). Pengaruh profitabilitas, inflasi, dan kurs terhadap harga saham Indeks Perfindo 25. Motivasi: jurnal Manajemen dan Bisnis, 3(1). 433-446.

Atidhira, A. T. (2017). The influence of return on asset, debt to equity ratio, earnings per share, and company size on share return in property and real estate companies. Journal of Applied Accounting and Finance, 1(2), page 128-146.

Brigham, E.F., dan Houston, J.F. (2016). Dasar-DasarManajemenKeuangan. Edisi10. Salemba Empat.

Cahyani, N., \&Winarto, H. (2017).Pengaruh return on equity, earning per share dan debt to equity terhadap harga saham pada PT. Medco Energi Internasional Tbk. Jurnal Manajemen Bisnis Krisna dwipayana, 5(2).

Darmadji \& Fakhrudin. (2012). Pasar Modal di Indonesia (pendekatantanyajawab), Edisi Ketiga. Salemba Empat.

Darsono \& Ashari. (2015). Pedoman Praktis Memahami : Laporan Keuangan. Edisi 1. Penerbit Andi.

Diaz, R., \&Jufrizen. (2014). Pengaruh return on assets (roa) dan return onequity (roe) terhadap earning per share (eps) pada perusahaan asuransi yang terdaftar di Bursa Efek Indonesia. Jurnal Manajemen dan Bisnis, 14(2).128-133.

Egam, G. E. Y., Ilat, V., \& Pangerapan. (2017). Pengaruh return on asset (ROA), return on equity (ROE), net profit margin (NPM), dan earning per share (EPS) terhadap harga saham perusahaan yang tergabung dalam Indeks LQ 45 di Bursa Efek Indonesia periodetahun2013-2015. Jurnal EMBA, 5(1). 105-114.

Fahmi\&Hadi, Y.L (2012). Teori Portofolio dan Analisi Investasi. Alfabeta.

Fahmi, I. (2012). Pengantar Pasar Modal. Alfabeta.

Fauzi, F., Dencik, A. B., \&Asiati, D. I. (2019). Metodologi Penelitian Untuk Manajemen Dan Akuntansi. Salemba Empat.

Febriani, Rio, (2016). Pengaruh ROA, ROE, EPS, dan CR terhadap return saham pada perusahaan yang terdaftar di Indeks LQ 45 di Bursa Efek Indonesia tahun 2011-2015. $e$ Proceeding of Management, 3(1).

Gitman, L. J. (2012). Principal of Managerial Finance, (Thirteenth Edition ed.). Addison Wesley.

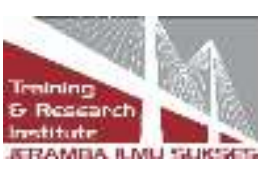


Hanafi, M. M., Halim, Abdul. (2016). Analisis Laporan Keuangan, Edisi Lima. UPP STIE YKPN.

Harahap, Sofyan Syafri. (2015). Analisis Kritis Atas Laporan Keuangan, Cetakan Ketiga. PT. Raja Grafindo Persada.

Hutami, R. P. (2012). Pengaruh dividend per share, return on equity dan net profit margin terhadap harga saham perusahaaan industri manufaktur yang tercatat di Bursa Efek Indonesia periode 2006-2010. Jurnal Nominal, I(I). 104-123.

Kamruzzaman. Md (2019). Impact of the financial factors on return on assets (ROA): a study on ACME. International University Journal of Business and Entrepreneurship, 12(1), 50-61.

Kasmir.(2012). Pengantar Manajemen Keuangan, Edisi Revisi. Penerbit Kencana.

Keown, A. J., Martin, J. D., William, W. J., \& Scott Jr, D. F. (2012). Financial Management Principles and Applications, Ninth Edition. Prentice-Hall.

Munawir.(2012). Analisis Laporan Keuangan, Edisi Keempat, Cetakan Kelima. Liberty.

Rosalina, L. \&Masditok, T. (2018). Pengaruh ROA, ROE, DER, dan EPS terhadap harga saham perusahaan Sub Sektor Transportasi di BEI Periode 2012-2016, Jurnal Akutansi, Audit dan Sistem Informasi Akutansi (JASa),2(4).

Simatupang, Mangasa. (2010). Pengetahuan Praktis Investasi Saham dan Reksadana. Penerbit Mitra Wacana Media.

Sitorus, T., \& Elinarty, S. (2017). The influence of liquidity and profitability toward the growth at stock price mediated by the dividends paid out (Case in banks listed in Indonesia Stock Exchange). Journal of Economics, Business, and accountancy Ventura.19(3). 377392.

Sutrisno.(2012). Manajemen Keuangan Teori, Konsep dan Aplikasi, Edisi 8. Ekonisia.

Tandelilin, Eduardus. 2010. Portofolio dan Investasi. Edisi Pertama. Kanisius.

Wardjono. (2010). Analisis faktor-faktor yang mempengaruhi price to book value dan implikasinya pada return saham, Dinamika Keuangan dan Perbankan , 2.(1). 83-96.

\section{Copyrights}

Copyright for this article is retained by the author(s), with first publication rights granted to the journal.

This is an open-access article distributed under the terms and conditions of the Creative Commons Attribution license (http://creativecommons.org/licenses/by/4.0/) 